ESSAY

\title{
Growing Up Haitian in Black Miami: A Narrative in Three Acts
}

\author{
Jemima Pierre \\ University of California, Los Angeles, US \\ pierrej@ucla.edu
}

Jemima Pierre reflects on growing up Black in Miami and how it has shaped her intellectual pursuits.

Keywords: Haitian; Little Haiti; North Miami Beach; institutions of respectability; language

\section{Act 1: Saturday, April 27, 2013}

It is early afternoon and I am in the second of the three white limousines filled with family members at the head of a long funeral procession. We are slowly making our way on the Palmetto Express way (Highway SR 826) to the Vista Memorial Gardens in Miami Lakes. Barely able to contain my grief, I fix my eyes on the road outside. It is then that I realize that our entire side of the Palmetto Expressway had been closed off-with ramp entry after ramp entry blocked by escort police on motorcycles-in an effort to accommodate the massive procession of cars. Somehow, the eighty-plus Haitian pastors on the stage at Bethel Evangelical Baptiste Church, the large contingent of officials representing the national office of the Church of the Nazarene, or the hundreds of people that attended my father's funeral, did not surprise me as much as the closing of that entire side of the Palmetto Expressway. At that moment, looking out at the long car procession, I understood the importance of this church community, my community. I also came to terms with the significance of my father's legacy in Miami and, in particular, its Haitian community.

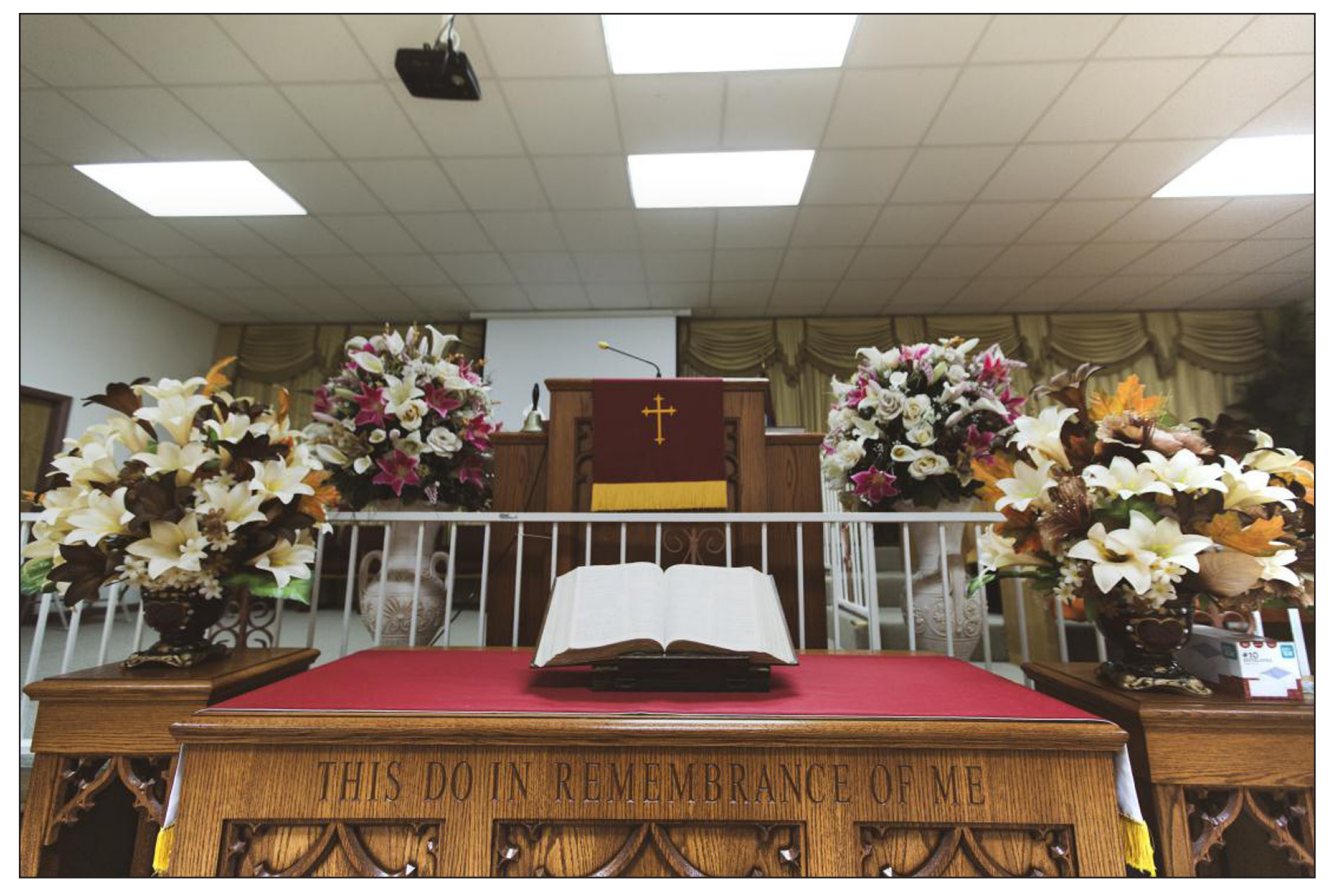

Altar of Miami Peniel Church of the Nazarene. Photo credit Barry Williams. 
My father, the late Reverend Delanot Pierre, was the co-founder ${ }^{1}$ and pastor of the Miami Peniel Church of the Nazarene. Before that, he had been part of the first generation of young Haitian men trained in the first theological school set up in Haiti by the U.S.-based Church of the Nazarene mission. ${ }^{2}$ After graduation and official ordainment, he would quickly rise through the ranks of the Church of Nazarene in Haiti, ultimately serving as Superintendent of churches for the country's Northern Region. In 1976, while attending the Church's General Assembly meeting in Dallas, Texas, he made the decision to formally migrate to the U.S. In recalling that decision, my father said that he had never intended to leave Haiti. However, a number of key events helped make the decision for him. One of these was his abduction and brief detention, presumably by the secret police of Jean Claude "Baby Doc" Duvalier, after an evening sermon that was deemed politically charged. In addition, the Church of the Nazarene's internationalization process, which wanted to shift dependence on local Haitian leadership of the church mission, also meant a reduction of work benefits. New Haitian pastors were cheaper for the mission as they seemingly did not require similar economic investments for upkeep as early white expatriate ministers and missionaries stationed in Haiti.

The decision to leave Haiti would have a profound impact not only on our family but also for our relationship with the church. My father migrated from Haiti in 1977, leaving the rest of the family behind in Port-au-Prince. Two years later, my mother joined him in Miami. My sister and I remained behind in Port-au-Prince with her two sisters, our aunts, who were single young women. ${ }^{3}$ The aunts took custody of us and were our legal guardians for two years, until November 1981, when we were able to reunite with our parents. (It is important to state here that we benefitted from Jimmy Carter's liberal immigration laws, especially those that allowed regularization (green card) and family reunification. My family was given permanent residency status in the U.S. before we even arrived in Florida. And we came right before the crunch of the early 1980s when the presidency of Ronald Reagan reversed course on some of these early immigration benefits.)

Similar to other immigrants, my father worked hard to settle in Miami. He took up a number of jobs, beginning as a dishwasher at Denny's Restaurant and ending up with the strenuous and vexing job as a South Florida taxi driver-a job he would continue to hold until 2010, when he retired at the age of 65 years old (even as he continued to serve as full time Pastor at Peniel Church of the Nazarene). As my father became more established in Miami in the late 1970s, his involvement in the church (especially Haitian migrant churches) was constant. This participation provided him with not only a spiritual base but also a social, political, and cultural community. Indeed, it was only a few years after co-founding Peniel Church of the Nazarene that he would also co-found what eventually became the hundreds strong Association of Haitian Pastors and Churches of the Nazarene for the U.S. and Canada regions.

When my mother, my siblings, and I began planning Rev. Pierre's funeral, we quickly realized that our church building could not possibly accommodate the large number of people-from the Caribbean, throughout the U.S., and Canada-who were planning to attend. We had to search for a much larger building than the one that housed Miami Peniel. We settled on Bethel Baptiste Church, a congregation led by his colleague, which was housed in a large building in a large former shopping plaza. On the day of the funeral, core members of his church, along with family members, first stopped at Miami Peniel and wheeled his casket up to the pulpit-his pulpit-and held a private service for him. It was his last goodbye to the church he had built. After a brief service and ceremony in his honor, where we sang his favorite song ("Lè la vi mwen va fini") and read his favorite Bible verse, we proceeded to Bethel Baptiste where the formal funeral would be held.

Founded by a group of Haitian immigrants in March 1981, including my mother, Mrs. Lisette Pierre, Miami Peniel Church of the Nazarene was my entry into the U.S. (In fact, I distinctly remember first arriving in Miami from Port-au-Prince on November 22, 1981, a Sunday afternoon, and having to attend service with my parents that very evening.) Indeed, the Haitian church in general, and Miami Peniel in particular, was also the entry point for many other Haitian immigrants arriving in Miami in the early 1980s. We, newly

\footnotetext{
${ }^{1}$ Miami Peniel Church of the Nazarene in was founded in March 1981 by a small group of Haitian immigrant friends and co-parishioners.

2 The Church of the Nazarene is a Protestant church in the "Wesleyan-Holiness" tradition. The church was organized in 1908, and now boasts 2.5 million members in more than 30,000 local congregations in 162 world areas. Haiti has the fourth largest Nazarene Population after the U.S., Mozambique, Brazil, and India. The theological school-Séminaire Théologique Nazaréen d'Haiti-was established in Petionville, Haiti, as part of the Church's internationalization strategy. My father, Delanot Pierre, matriculated in 1969.

${ }^{3}$ This is, of course, a normal occurrence for migrating families, where children are often left behind as parents forge ahead to establish life (and, as often, entire families are not allowed to migrate together).
} 


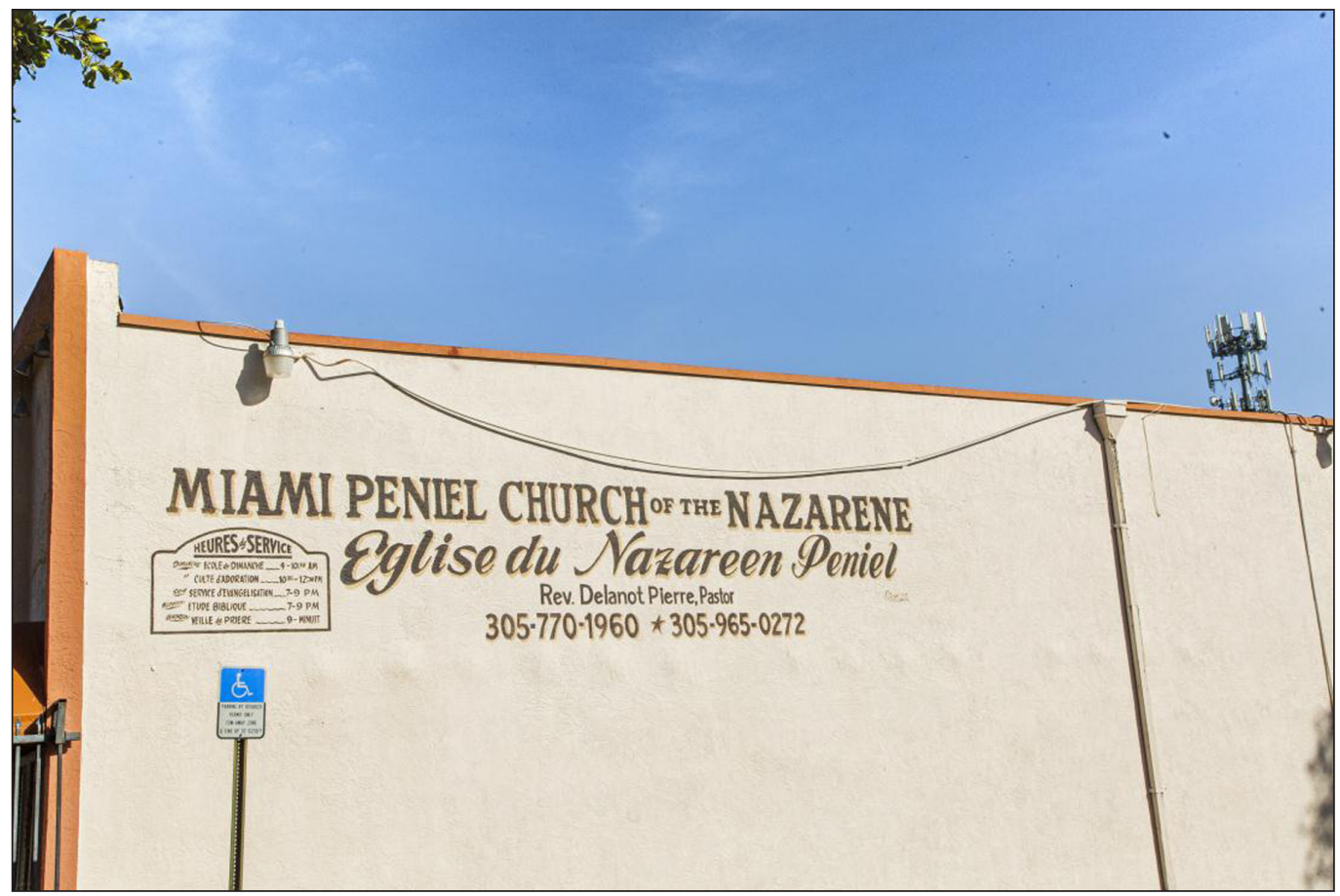

The exterior of the Miami Peniel Church of the Nazarene still bears the name of Reverend Delanot Pierre in 2019. Photo credit Barry Williams.

arrived Black migrants, were quickly caught up in the convergence of significant events during a turbulent Miami in the early 1980s: the discovery of HIV/AIDS and the crisis that it generated (as well as the racist implication that Haitian immigrants were the primary bearers of the disease in the U.S.); the large scale migration of Haitian asylum seekers (derisively labeled "boat people") to South Florida; the Mariel boatlift that brought 10,000 Cuban migrants to Miami; the 1980 protests of the Black community in the Overtown and Liberty City neighborhoods after the acquittal of four white police officers who murdered 33 year old Arthur McDuffie. These events were significant for my emotional and cultural development. They were also traumatic. As a young child (I was eight years old when I arrived in 1981) in a new country with limited English language skills, I had to confront the daily humiliation of being Haitian. Other young kids identified me as part of the group of undocumented and diseased "boat people" (despite the fact that our own family came to the U.S. by commercial airline, and that we, similar to most Haitian people, were not infected with HIV). We bore the brunt of the ignorance of young U.S. children-of all races and nationalities-who often taunted us, threatened to beat us up after school, and were convinced that we all had "HBO" (Haitian Body Odor). Our experiences, as immigrant and Black children in Miami's public school system, seemed to mirror the treatment of Haitian asylum seekers by the broader society. For example, by early 1980s, Haitian asylum seekers were some of first to be jailed, indefinitely, by the U.S. government, a practice that went directly against U.S. law on asylum seekers. The infamous Krome Detention Center became the site of illegality and state-sanctioned violence and misery. Krome's human rights abuses were so notorious that, in 1982, almost 2000 Haitian asylum seekers were ordered released by a Federal judge. Those asylum seekers with family in South Florida were released to these family members. Others were released to volunteer associations and/or sponsors.

Miami Peniel Church, along with a number of other Haitian churches, served as sponsors for the newly released asylum seekers, providing food, shelter, and company to people who had been detained for months, even years. The churches also worked to connect these asylum seekers to family members-either in Florida or other places in the U.S. northeast. Our church's rapidly growing membership reflected this new reality of ongoing immigration to South Florida. ${ }^{4}$ We were always welcoming new members from this migrationand poor and working-class Haitian migrants made up (and continue to make up) the bulk of the church membership. Some would only attend when there was a break in the farming season (since many worked as

\footnotetext{
${ }^{4}$ The influx of Haitians reached a high point in 1980, when approximately 25,000 Haitians came to South Florida seeking asylum (https://thenewtropic.com/history-little-haiti/).
} 
farm laborers in the Imokalee tomato fields or the bean fields of Homestead); others worked in factories, the hotel and restaurant industries. Some of the younger women immigrants were able to attend the apprentice programs that earned them certificates to work as Certified Nursing Assistants (CNAs) and, later, as Licensed Practical Nurses (LPNs). These women, my mother among them, often provided the backbreaking work of elderly patient care in South Florida's numerous convalescent homes. And, a large majority of the Haitian immigrant men took up driving taxis-an ideal job because it allowed a level of autonomy and freedom from society's prejudices. Our church community, in turn, kept Haiti very much alive among the immigrants-and in our household. My French and Haitian Kreyol ("Kreyol Ayisyen") speaking and reading ability, for example, continued to get better, as church service and sermons, were conducted in these two languages. Even our Bibles and song books were in French and Kreyol. This was significant for me as a young elementary school child quickly learning English, which, barring the church, would have ultimately replaced my first two languages.

The church, then, was not only a spiritual place but also cultural and political space. It was also one where I made my early and longstanding friendships - in the context of Sunday school classes, youth programming at the church on Sunday afternoons, Wednesday and Friday evening prayers, the summer Saturday picnics at Haulover Beach, and the church's yearly $4^{\text {th }}$ of July trips to Walt Disney World in Orlando, Florida.

This church community context is important because the world outside of the church hall was all but comforting. The impact of the HIV/AIDS epidemic on Miami's Haitian immigrant community-and especially on the children of that community-was devastating. And it was not because Haitian immigrants were the majority of HIV/AIDS carriers. Rather, we were victims of anti-Black stereotypes and racism that brought together the circumstance of migration (people coming to Miami shores from Haiti by the boatloads) and the racist designation by the CDC of the category "Haitian" as high risk for AIDS (the only time a sole nationality was linked to disease). ${ }^{5}$ This is some of what I remember: 1) having to run home from elementary school trailed by kids who wanted to beat me up because of a combination of reasons: I was Haitian and therefore had "HBO," or I had touched a classmate's pen and had potentially given her or him AIDS; 2) having to pretend to be from the Bahamas instead of Haiti. This meant not inviting anyone to our house, not giving my home phone number in the likely terrible scenario that one of my parents would answer the phone and my Haitian identity would be given away. The other thing I remember is being publicly shamed and turned away from donating blood during the high school blood drive because the Food and Drug Administration had banned Haitians from donating blood. I also remember whispers among adult members of the church of children committing suicide because of the shame of being Haitian and the trauma of being bullied. Or, even worse for the church parents, of children dropping out of school and pursuing a life of crime.

Thinking back to these times of trauma, it is a wonder so many of us kids survived. But I also think that the Black American and non-Haitian Caribbean kids at my elementary and junior high school who made picking on Haitian kids sport were also victims of the anti-Black racism of the times. With distance, it was clear that the white supremacist construction of Haitian immigrants-as weird-language speaking, voodoo-practicing Black, dirty, diseased "boat people"-embarrassed these young people. After all, what Black eight-year old wants to be associated with those people-who look like them-and who were always in the news for something bad. The Black American and non-Haitian Caribbean kids did not want to be associated with Haitian immigrant kids because the Haitian kids' Blackness also implicated them. So they coped the way kids do-through explicit and very public distancing.

The church community, the church activities, and the early church friendships, however, crowded out those distressing and racist stereotypes and the associated treatment of school bullies. I don't remember the youth in our church ever actually discussing our precarious predicament during the early 1980s. Maybe it wasn't necessary. There was no space for that in our community because, beyond the issue of negative representation, was the ongoing effort to survive. We were economically poor. Collectively, our parents worked lower class jobs-taxi drivers, security guards, nursing assistants, hotel housekeeping, factory and farm hands-and spent more time at work than at home as they struggled to make ends meet. Many of us benefitted from citywide anti-poverty initiatives that donated food and household products to the church

\footnotetext{
${ }^{5}$ Here, Edwidge Danticat writes of the impact of the AIDS crisis on the Haitian immigrant community: "Haitians were the only ones solely identified by nationality, in part because of twenty or so Haitian patients who'd shown up at Jackson Memorial Hospital, in Miami. 'We forwarded these cases to the C.D.C.' Dr. Arthur Fournier, who treated some of those first Haitian patients, told me recently. 'The media then took off with the sensationalistic headlines.' Suddenly, every Haitian was suspected of having AIDS." (https://www.newyorker.com/news/news-desk/trump-reopens-an-old-wound-for-haitians)
} 


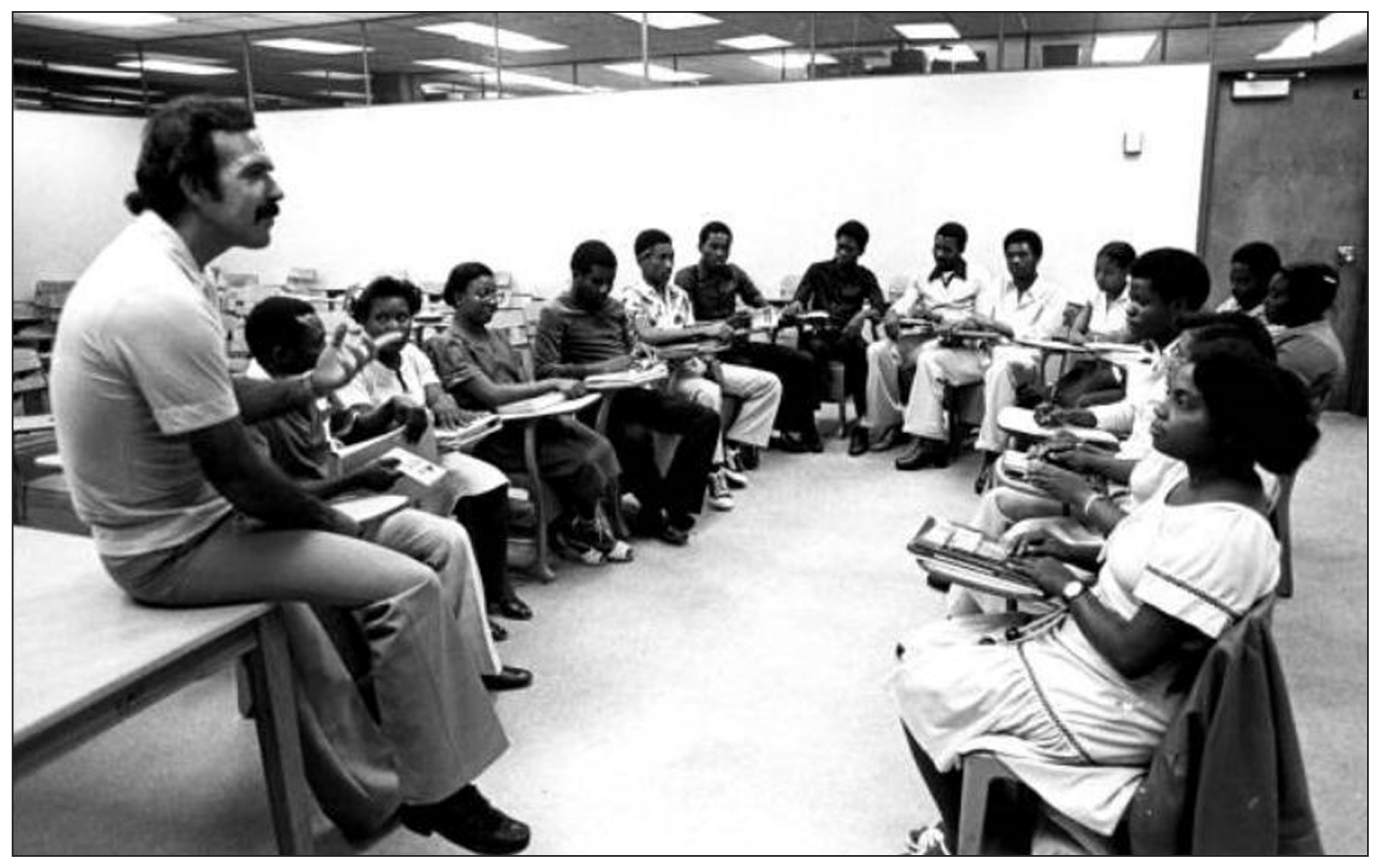

Older Haitian teenagers participate in Miami-Dade Community College classes for new immigrants at MDCC Outreach Center in Liberty City. Photo courtesy of the State Archives of Florida.

for distribution. This was community survival. The church was our survival. And what this closing of ranks of the Haitian immigrant church community meant for us children was that our Blackness, which was also linked to our class position, was wrapped up in our Haitianness-in both a bad way (external racism) and in a good way (community formation in spite of it all). And, to be honest, Blackness was something we hardly thought about in a concrete way. As kids, we thought we were being picked on because we were Haitian, not Black-especially since, in our schools, it was the Black kids who were often (though not exclusively) the antagonizers. This is so even though we were very aware that to be Haitian in Miami was to be Black-but a particular kind of Black. It is a contradiction that I could not explain. But it was our reality.

As we kids got older in the church-becoming more "American" and less Haitian-the church community seemed to quickly become an impediment, a site of cultural and political clashes. The church community, while an oasis in many ways, was by this time, far from a progressive presence in our lives. To demonstrate, I will briefly focus on three of its specific features: the entrenched patriarchy; the response to education; and the deployment of religion. As a young girl, and as the oldest of my parents' five children, it was clear that my trajectory once I neared adulthood was to be married early-and to one of the men in the church. And the men began trying to "court" us teenage girls when we were in high school. These were not men our age, to be sure. They were often in their later 20s, early 30s, whose devotion to the Lord and the church meant, as my father would constantly remind the youth, "there's no such thing as 'dating;' there's only marriage." To be clear, my parents never told me that I needed to marry by the end of high school. I was, after all, my father's smart child, a gifted student who, if I were a boy, would have been expected to follow in his footsteps and become a Church of the Nazarene minister. Since I was not a boy, but a smart girl, they thought that I would at least one day attend college. But for us-children in the house as well as the larger church community"college" only meant Miami Dade Community College. And this is the feature of the perceived role of education for the church. Among church parishioners-the bulk of who were from the Haitian countryside with little formal education, and who did not know of or understand the concept of higher education-attending Miami Dade Community College was the symbol of immigrant integration and accomplishment. The smart and "successful" people we knew had attended or were attending college (Miami Dade Community CollegeNorth Campus). And while my father had attended and graduated from Theological School, it still was not perceived as sophisticated as Miami Dade. (Though the Moody Bible Institute or the Trevecca Nazarene University would eventually come into my father's radar.) In all of this the important message was that church came first-most times, certainly before education (or, rather, secular education). This mantra was folded into the church's patriarchy and carried to its logical conclusions when extra-curricular activities (such as when my participation in the Math Club, in the marching band, or in the school choir) demanded 
time away from church or, sacrilegiously, time away from Saturday morning girl-designated chores. It was the disciplining clash between religion and education, between cultures-which extended into our home (and which meant, for me, a particular kind of integration into the broader US society)-that led me to venture out of the cocoon of the Miami Haitian church community.

\section{Act 2: Usually after school, between 1988 and 1990}

Just as the church was an outlet from the racist times of the early 1980s, high school was an outlet from church. As the Miami Haitian immigrant community grew exponentially, "Little Haiti," came into being. The boundaries of Little Haiti remain unclear and contested, but those who knew, knew. When I first arrived to the U.S. with my younger sister, our parents were living in a tiny apartment on 81 St (N.E.) very near Biscayne Blvd. That address remains etched in my memory because, just two blocks away, on $79^{\text {th }}$ street and Biscayne Boulevard, was the then iconic INS ${ }^{6}$ building, a tall and imposing, 12-story building flanked

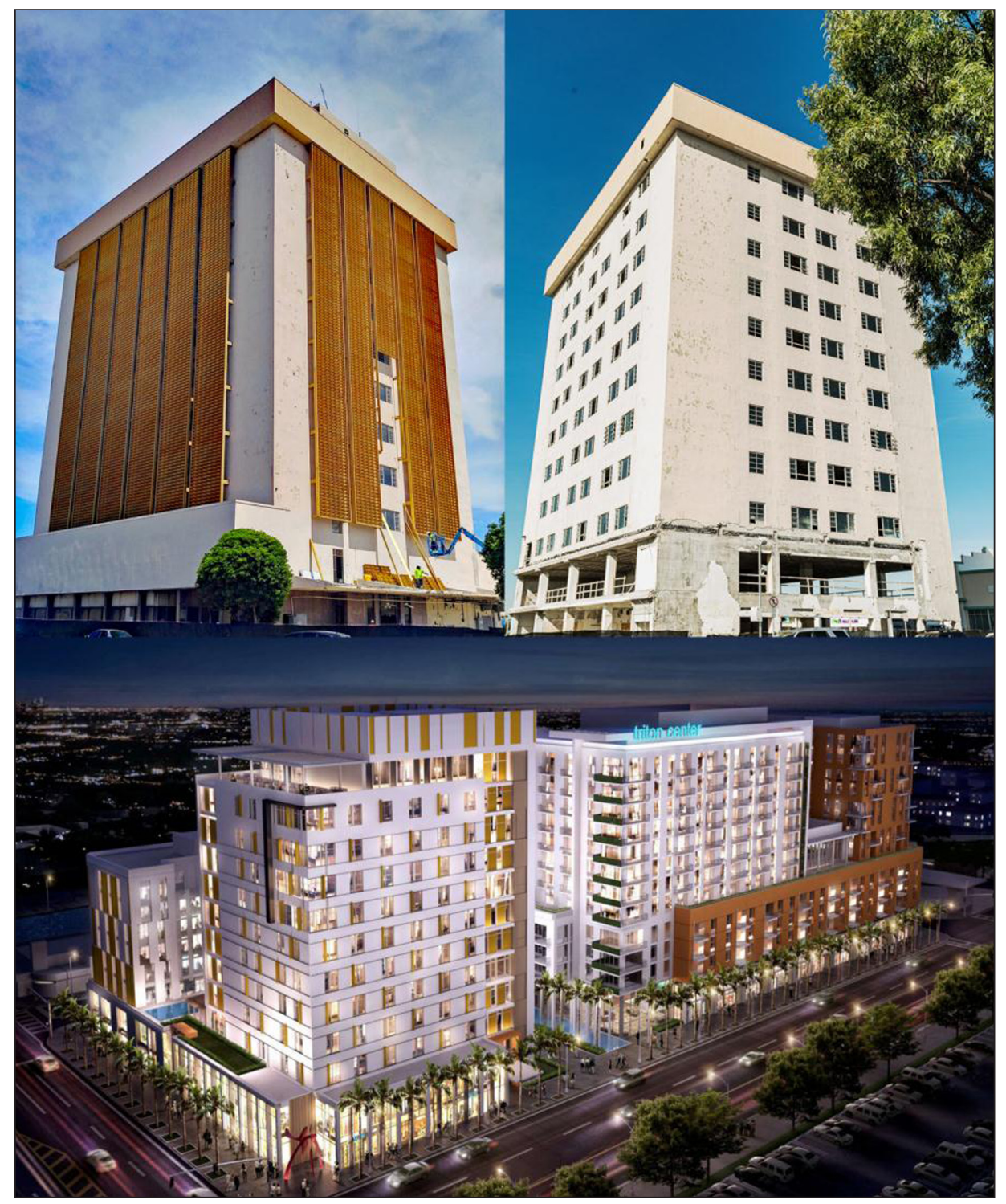

The original Immigration and Naturalization Service offices, which played a huge part in the lives of immigrants coming to Miami as a site of both assistance and surveillance. The building has been recently purchased by developers and will be renovated into a multi-use luxury complex.

\footnotetext{
${ }^{6}$ INS is the Immigration and Naturalization Service. It was an agency of both the U.S. Department of Labor and U.S. Department of Justice that was tasked with administering immigration and naturalization matters. The agency was disbanded in 2003, and its functions folded into various entities (including U.S. Immigration and Customs Enforcement (ICE)) within the newly created Department of Homeland Security.
} 
with unique mid-century styled gold anodized aluminum panels. The INS building was so much a part of our lives because it controlled much of our lives as immigrants-it was where we had to go for every issue dealing with our presence in the U.S. But I remember distinctly that our family's apartment was on the very north edge of "Little Haiti." Indeed, for us, Little Haiti was where the church parishioners lived and where our church was located. Miami Peniel Church changed locations three times $-54^{\text {th }}$ Street, $29^{\text {th }}$ Street, and settling finally in what quickly became the heart of Little Haiti, on $58^{\text {th }}$ Street and $2^{\text {nd }}$ Ave (N.E.). When my father drove the church van to pick up parishioners, all his twists and turns were within an unmarked boundary, between $29^{\text {th }}$ street (to the south) and $79^{\text {th }}$ street (to the north), and between $7^{\text {th }}$ Ave, NW (to the west), and Biscayne Blvd (to the east). Indeed, I remember that the vast majority of the church's parishioners lived in a large apartment complex, Sabal Palm Apartments, on $53^{\text {rd }}$ Street and $3^{\text {rd }}$ Ave, N.E. As Haitian immigrants began integrating into these new communities, Miami-area writer Rob Goyanes points out, "Local institutions that had been predominantly African American or Hispanic took on a new Haitian identity, including Edison Middle and Edison High School. ${ }^{7}$ Very quickly, schools in the area became known as "Little Haiti," as they were identified primarily with Haitian immigrants. Edison High School, for example, became (derisively) known as "Haiti High." The shift in a school like Edison (and other schools around southern Florida) to a population that was predominantly Black and immigrant (and especially a distinctly Haitian Blackness) also came with a broad set problematic changes that were structural, cultural, and political. Before the influx of the Haitian immigrant children, Edison Middle and High schools already had a predominantly Black American population-with all the negative connotations, and divestment, that this meant in a white supremacist nation such as the U.S. Adding Haitian immigrant children made the space seem "hyperBlack." The result was a narrative of these schools as "bad" schools. Of course, for many local government disinvestment (in public education in general, and Black public education more specifically) was not seen as the culprit-the character of the schools' populations was blamed.

Similar to many other people (immigrants and non-immigrants alike), my parents bought into the idea that neighborhoods and schools with Haitian immigrants (and Black people more generally) were of inferior quality. (I would also suggest that they also believed these neighborhoods and schools to be "bad." Indeed, they would tell us that these places were filled with "Black American drug dealers" and increasing violence.) My parents therefore made the decision very early on to move us far away from "Little Haiti" for the purpose of having access to better schools. Within two years of our arrival to the U.S. (and soon after my mother had given birth to another child, my sister), the family moved from the edge of Little Haiti on $81^{\text {st }}$ street to the heart of North Miami Beach, on the N.E. side of $168^{\text {th }}$ street. I vividly remember this neighborhood. It was a neighborhood of vast apartment complexes, with a large and predominantly white retirement population. Our family settled into a larger apartment, and my sister and I began attending the elementary school of the neighborhood-Fulford Elementary.

This move would have extreme ramifications for us. I do not recall much of the racial make-up of Fulford Elementary School. But I do remember that both my $5^{\text {th }}$ and $6^{\text {th }}$ grade teachers were Black men and the school principal was a Black woman. When I review school pictures, I see that I attended a racially diverse school that was filled with mostly nonwhite students. The school was not predominantly Black, but it had what seemed to be a range of non-white and immigrant children. Children from Fulford Elementary School were expected to matriculate in a few Junior High Schools; my sister and I attended John F. Kenney Junior High.

It was at JFK that I first became intimately acquainted with one part of Miami's large Jewish population. JFK was located in the city of North Miami Beach on $167^{\text {th }}$ street, between NE $10^{\text {th }}$ and $12^{\text {th }}$ avenues. The neighborhood spanning the area north and west of JFK Junior High was known as a middle-class neighborhood of devout (if not primarily Orthodox) Jews. That neighborhood had much of the Jewish cultural infrastructure, with a number of Synagogues and community centers. ${ }^{8}$ Because I was an active student at JFK, member of Mu Alpha Theta, ${ }^{9}$ and participant in other extracurricular activities, I remember seeing groups of Jewish family members walking to religious events when I attended my programs afterschool on Fridays and on Saturday mornings (when math competitions would take place). As a school, JFK was racially diverse, but predominantly white, with the white population seemingly predominantly Jewish. Towards the end of my tenure at JFK, and in a growing family (by now my mother had had one more child born in the U.S. and

\footnotetext{
${ }^{7}$ https://thenewtropic.com/history-little-haiti/.

${ }^{8}$ This neighborhood remains, to this day, predominantly Jewish and middle class.

${ }^{9}$ This is the math club.
} 
we now numbered four children), my parents moved the family even further north to the northern edge of North Miami Beach to a new city called "Miami Gardens," which put us close to the line that separated Dade County from Broward County.

When we moved to our little house on $193^{\text {rd }}$ Terrace (between North Miami Ave and $1^{\text {st }}$ Ave, NW), we kids were in for a shock. My parents had bought their first (and only) house. It seemed like a miracle to us. But back then, the Haitian immigrant community (especially members of the church), came up with innovative ways to save and share funds to help individual families build up collateral in order to be approved for bank loans. Quite a few of them were successful in buying houses. In any case, I'm not sure how they managed this, but we were the very first Black family on our block. Except for our schoolmates, we had never been near so many white people. Most of the neighbors did not engage with us, though a couple of them would greet us. And within a year, however, most of the white families on the block had either sold their houses or were in the process of selling. I remember only two white families who stayed behind-one had an old French patriarch who liked to sit shirtless on his porch. (I mention this because, as child, all I remember thinking every time I saw him was how red his skin looked. He often looked sunburnt-no doubt as a result of him spending most of the day in the sun.) We liked him because he was nice to us children as we walked by to go the 7-Eleven near his house. He would always greet us and speak to us in French. This small act of kindness meant a lot to us, especially in the context of a neighborhood in full (white) flight and broader Miami racial politics. The other white family that stayed behind had a retired older woman who, perhaps, had nowhere to go. We hardly saw her. For both this woman and the older French man, it was their death that removed them from the block. After that, we had no more white people on the block or in the neighborhood.

Moving so far north and west of North Miami Beach meant that we were now in a different school district. Our new high school should have been Miami Norland Senior High School, which began as an all-white, segregated, school and became majority Black by the mid-1980s. My parents, having bought into the hegemonic ideology that predominantly Black schools were "bad" schools, decided not to send us to that school. My sister and I were elated! We had already been insisting on attending the main feeder high school for JFK, North Miami Beach Senior High School (NMB), which was located right next to JFK and had a stellar academic reputation. Because NMB was still a predominantly white school, we convinced our parents to apply for a "[Racial] Majority-to-Minority" transfer (a desegregation policy instituted by Dade County Schools). My sister and I were able to attend NMB for the duration of high school. (A decade later, our younger siblings were not able to receive the Majority/Minority transfers and were forced to attend Norland High School).

Being a student at NMB transformed my life and outlook. Because I had good grades, I was placed in all honors and "Advanced Placement" (AP) classes. This meant that, from the beginning of my tenure in high school, I was surrounded by white kids and white teachers. Indeed, most of my teachers in high schoolthose who taught the honors and advanced placement classes, and ran extracurricular academic activities in which I participated, such as Mu Alpha Theta (the math club)-had Ph.D.s. I didn't realize back then how extraordinary this experience was for public school. I was very aware, however, that I was at once the exceptionalized Black student, but I was also the one who Dr. Lavin could never give a grade above a " $\mathrm{C}$ " in any assignment in advanced placement $11^{\text {th }}$ grade English.

From $10^{\text {th }}$ grade on (my first year at NMB), there were only 3 other Black people in all my classes. The four of us were together in most of our academic classes throughout high school. We four were all immigrants or children of immigrants. I was born in Haiti, but Cindy was born in New York to Haitian immigrant parents. Of the other two, Kevin was born in Jamaica, and Robert was born in the U.S. to two Jamaican parents. We were close and felt extremely separated from the other Black students on campus. We were all aware, for example, that NMB's Black student population was a little under $20 \%$, but most of the Black students seemed to exist in a different world from our isolated ones. Cindy and I seemed to acclimate more to the white cultural milieu whereas Kevin and Robert were always cynical and dismissive of the students and teachers. Perhaps it was because, as boys, they were treated differently than Cindy and me. Perhaps it was because they were brilliant and made school look easy, while the white kids were always fretting and planning, or perhaps it was because they had interests outside of school.

My NMB academic-but not social-world was one where the majority of my classmates were white and seemed to be wealthy, and most of that population was from the upper-class Jewish communities. ${ }^{10}$ Whereas the Jewish kids in JFK Jr. High often came from the surrounding middle class (and seemingly more orthodox)

\footnotetext{
${ }^{10}$ Much of the city's postwar development can be traced to early Jewish influxes of the 1940s-1960s from New York and the rest of
} the Northeast U.S. 
neighborhood, the kids at NMB came from more upper-class enclaves-around the neighborhoods of Aventura (which would later incorporate as its own city) and the general NE Dade County border. This was a new world. Most of my interactions around schoolwork and other academic activities were with these kids. We studied for exams together or worked on group projects (usually after school in the library of the north campus of Florida International University). In the process, I learned much about the lives these kids livedeven from afar-and became intimate with their social and cultural practices. I was rarely invited to their homes, but I would sometimes attend the occasional group meeting at a restaurant or diner in the Aventura area on Biscayne Boulevard. This was a different cultural milieu from either my Haitian church community or small group of Black and Brown kids (from school) that I often socialized with. From what I remember, the bulk of our conversations in these gatherings were about college preparation. We discussed the best classes to take, why it was important for all our classes to be "advanced-placement"-especially during the $11^{\text {th }}$ grade-so that we could boost our grade point averages for college applications, ${ }^{11}$ and which teachers to stay clear of. I also learned that most of these students were enrolled in "SAT prep" courses from the $10^{\text {th }}$ grade, and many had personal tutors. It was during these times that I was made acutely aware of my class position within this group. My family did not have access to the extra \$500 needed for these exam prep courses, or to pay extra for tutoring if I were struggling with class assignments.

Nor could my parents afford to buy me a car, and much less a sports car, in the $10^{\text {th }}$ grade. That most of these kids received new cars when they turned 16 seemed to be a remarkable occurrence. I had never seen so much wealth or such conspicuous consumption. I remember my classmate, Andy, who gave me a ride in his brand-new Ford Probe, and Scott, who took Cindy to Prom in his "second-hand" new Audi sports coupe. ${ }^{12}$ I also remember the types of clothes and jewelry the girls wore, the fact that they would go to salons for manicures and to straighten their curly hair, and the talk of summer travel to Israel or to other "exotic" places. I, on the other hand, got my first part time job at the age of 15 at the Taco Viva at the $163^{\text {rd }}$ Street Mall across the street from the school.

By the time I was hired at the job at Taco Viva, life at home for me (and the sister closest in age to me) was deteriorating. My parents were extremely strict, and that strictness, I believe, was intensified because it was also their immigrant response to the chaos of a new society. My father, as a minister and patriarch, controlled the house through religious dogma, cultural precedent, and immigrant fear of a violent and deeply sinful country of settlement. A profoundly religious man, my father believed the Bible to be our social guide, often took the Bible literally, and linked Haitian cultural taboos to religious dogma. For example, my sisters and I (and the other women and girls in the church) were not allowed to wear "men's clothes." This meant that jeans and pants were out of bounds. And at church, girls and women had to cover their heads (because, according to the Bible, women were not show their hair in public), and were not allowed to wear make-up or jewelry. In our household, we were also not allowed to participate in all things secular, and all the things that kids our age were doing: watch regular television, go to the movies, or attend music concerts. ${ }^{13}$ The only sanctioned television we were allowed to watch was the Trinity Broadcasting Network (TBN), which was Christian television. In addition to this, we were also restricted from most social things: we were not allowed to visit friends, have friends call us on the phone or have friends come over to our house. These strict rules greatly impacted my involvement in school activities-and my socialization. Thus, while I was allowed to participate in Saturday morning math competitions, my father (and, at times, my mother) would often argue that a girl's job is to clean the house on the weekends. This would often create friction between my sister and I-as we both had extracurricular activities on Saturday mornings (she was on the debate team)-and sometimes we would have to choose which one of us would miss our event. Out of town trips for choir, math, or debate competitions were out of the question!

The job at Taco Viva, therefore, felt like freedom. But since our family was also extremely poor, the job was also a great financial relief all around. It allowed me to finally purchase basic things for me and my teenage sister-updated shoes and clothes, in particular-and have some the spending money to do things that my

\footnotetext{
${ }^{11}$ I learned quickly that grades in an Advanced Placement (AP) class were weighted. Thus, on a 4.0 scale (where a regular "A" grade weighs, 4.0), an " $\mathrm{A}$ " in an AP class weighed 6.0 points. This meant that, even if one received a " $\mathrm{C}$ " grade in an AP class, it was equivalent to receiving an "A" in a regular class. In this sense, Dr. Lavin's " $C$ " did not hurt me much. But an "A" would have raised my weighted grade considerably. Indeed, most of my classmates graduated high school with grade point averages way above the 4.0, with the valedictorian having a 5.8 on a 4.0 scale.

${ }^{12}$ Our high school had two student parking lots, one for the wealthy kids with the sports cars, and the other-the public parking lot of the large 163rst Street shopping mall that faced the school-was for the rest of the kids with the less fancy cars.

13 This was also the time of the rise of Michael Jackson, Prince, and the concert tours, as well as the premier of Prince's Purple Rain movie.
} 


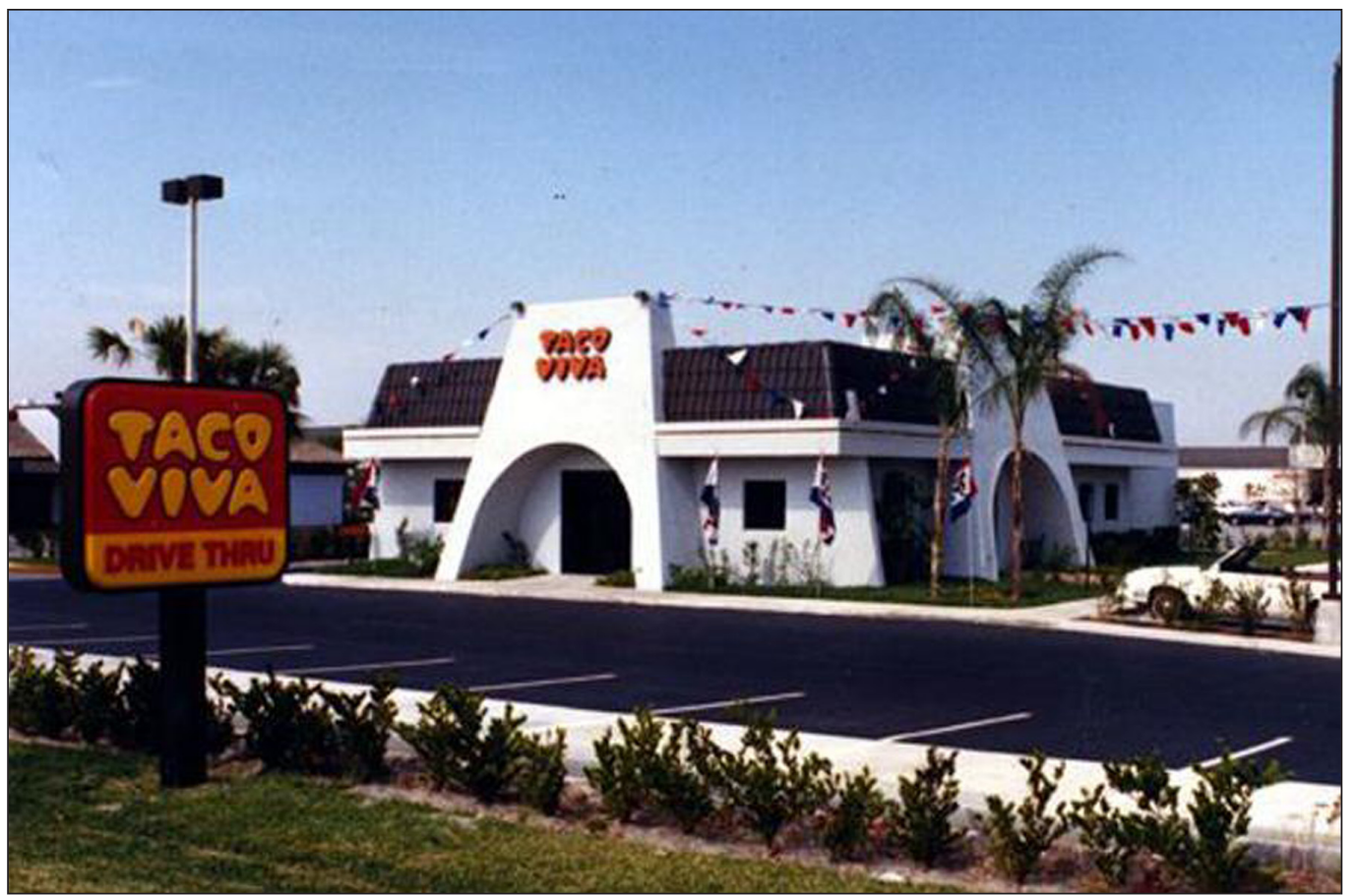

Taco Viva franchise, a fast food chain popular in South Florida in the 1980s and 1990s, now defunct. Photo credit www.tacoviva.com.

wealthier classmates were doing, such as dining out for lunch or buying gadgets. The job also gave me a bit of extra funds to pay for certain school activities. Working at Taco Viva meant breaking my parents' rules about dress and decorum. The uniform for work was black pants and a white shirt with the company's logo. I could not admit this to my parents, as this would have certainly made them stop me from working there. When I first began to work at Taco Viva, I had to borrow pants from a friend, because I did not own any. And, when I left for work from home, I would wear a skirt leaving the house and then change when I made it to work. I was soon able to by a couple pairs of pants for work but had to leave them with friends for fear of my parents finding them at home. Working at Taco Viva allowed me a freedom that I did not know existed. I was able to now see friends, stay out late (using work hours as excuse), and be in a different world. But it also came with its hazards, including the fact that the mostly young, Black, and female workforce faced constant sexual harassment from the white Cuban manager of the restaurant. We would often laugh it off, but we made sure to stay out of his way. We were all poor teenaged workers and we all badly needed the job. And we were all too young and naïve to know that we had the right to work without harassment.

By this time, my social world was not with the white Jewish kids-though we still studied together and interacted at school-but was with the other kids in the activities that I participated in: choir and marching band. By then, I was also part of a small tight-knit group of mostly immigrant friends. This small group included Martin, a Chinese-Jamaican boy; Marjorie, a Jamaican girl; Lilly, a Haitian-American girl; and Gabriel, a white Cuban boy. We were all working class or poor, and all had part-time jobs outside of school. Our friendship emerged from this context of work and socialization outside of school. In fact, Marjorie was the first (and only) of our group to purchase her own car. She practically lived on her own-as her mother was either working all the time or in Jamaica. Marjorie was the most enterprising of the group-she often worked jobs that were for older people (lying about her age) and was able to make more money than we could imagine as 15 and 16-year-old poor and immigrant high school students. The car she purchased-which became "our car"-was from a dealership where, through negotiations with the owner (whom she knew), she was able to arrange a payment of $\$ 50$ a week. When Marjorie could not make these payments, members of our group would often pitch in to help.

Because our high school was so large (with around 4,000 matriculating students in the late 1980s), it became easy to be anonymous when necessary. My social world seemed extremely contained-and I felt completely removed from the broader realities of high school life. To be sure, despite the restrictions imposed by family life, I was extremely active in school. I was a clarinetist in the marching band and sang alto in the school choir (and also participated in the small chamber choir and as a singer in the jazz band-as 
extracurricular activities). I even ran for school president during junior year! At the same time, I also remained active in church. We were in church all-day Sunday (Sunday School, Main Service, Youth Program, Evening Service), Wednesday night for Bible Study, and Friday prayer meetings (that met from 8pm-midnight). In hindsight, I am not sure how I was able to maintain this extra-curricular life-of school activities, work, and church-within such a strict household. I remember that, while I could not miss Sunday church services, my parents would allow me to miss those services on the weeknights when I had to work or had to study. But there were times when my teenaged sister and I would be told that church trumped everything, including our (secular) education. In this way, school was also a sanctuary for us. And this explains the role that the extracurricular activities played in our lives. They were freedom from a very restricted life-and-church-world that seemed to stifle our lives and imaginations.

This life-and-church-world came to an abrupt end when I decided, on the spur of the moment on a Sunday morning, that I would no longer attend Sunday church service. It was a usual Sunday morning in our house, and everyone was rushing around getting ready to leave for church. This usually meant that my mother would wake up first, make us breakfast and get herself and my younger brother and sister (who were toddlers) ready for church. My teenage sister and I were responsible for getting ourselves dressed when my father was ready to leave for church with the family. That Sunday morning, I woke up and decided that I was not going to church. It was an impromptu decision, but one that came after a months-long emotional, mental, and spiritual struggle around faith and purpose. A few weeks earlier, I had been given a book to read by my high school boyfriend, Robert (one of the two Black boys in all of my honors/AP classes). As a smart teenager, Robert was often on his own, reading and working on projects that had nothing to do with school. When we began dating, he would often suggest books to read that were very different than the books I was used to reading (such as the Sweet Valley High series or Judy Bloom books). For example, he suggested that I read Toni Morrison's The Bluest Eye, and we would discuss books such as James Baldwin's If Beale Street Could Talk. The book he gave me to read a few weeks earlier was Illusions: The Adventures of a Reluctant Messiah (1977) by Richard Bach. ${ }^{14}$ While I no longer remember the details of the book (and without currently researching and reviewing its actual contents), what I remember about Illusions is that it made me question the idea of one supreme God, one messiah, and one religion. It made me think that we (humans) all could be messiahs, and that religion itself was an illusion. I also remember that the book had a character, a regular man, who was considered a "messiah" and gained a large following for giving basic life advice. And the book was filled with quotes from this character about life and living. I was 16 years old by now, proud daughter of my father, and a whiz at the church's Bible quiz competitions. I was also very involved in church activities and considered myself to be deeply religious. But I also remember that, while church provided us with a community against the grotesque racism of the early 1980s, it could be scary place theologically. The mix of immigrant fear of U.S. social and cultural practices (especially the view of U.S. culture as permissive and promiscuous) coupled with religious dogma and patriarchy meant that we young people were caught in a terrible predicament. As many of us adopted and adapted the cultural practices of our peers and our new society, we were often told that these practices were sinful. Religious dogma seemed to serve as cover for countering cultural practices that our parents thought were unseemly. For example, boys in our church were told that they could not cut their hair in the popular high-top fade styles of the 1980s, because this reflected an "ungodly" look and represented "sinful" behavior of the Black American boys. It was the same with attending such events as school dances. More importantly, the threat of hell-literal hell-was always present in our church lives. I will never forget the Sunday evening when a white minister visited our church to broadcast his newly released film about sinners and hell. In this film, we watched as generation after generation (going back to the time of the old testament) of unbelievers end up in hell. Hell in this film was a literal place, a dark cavernous seemingly underground area where fires burned incessantly and where people never died, even as they were constantly fighting each other and suffering grotesque bodily harm. It was a place where multiple generations of sinners would meet each other and suffer together endless cruelty in eternity. That Sunday evening, when the film finished playing, the entire church was crying, with people dropping on their knees and begging god for forgiveness. I was not the same after that night; I was constantly afraid of behaving and even having thoughts that would result in me ending up in hell. Thus, the book Illusions found me at the right moment. Inadvertently, it helped release me from what felt like an environment of all-encompassing fear.

\footnotetext{
${ }^{14}$ Bach is better known for his book, Jonathan Livingston Seagull.
} 
Of course, nearly thirty years later, I realize that, compared to all the books I have read in my life, Illusions is not the most extraordinary. And the storyline is much more clichéd than I could have imagined. However, at that time in my young life, it is precisely the book I needed. The decision to not attend church that Sunday morning had life-changing repercussions. It destroyed the fabric of our family precisely because my actions not only challenged my father's patriarchy (structured through Haitian cultural mores) and dismissed my parents' own immigrant-inducing anxieties, but it also forever shifted the role of the church in my life. By the time I was a senior in high school, I was no longer living at home (I had left my home-and my parents and siblings-on my own accord) and was now living with a Jamaican family.

\section{Act 3: Any Given Sunday Afternoon, 1990-1991}

I don't know how many times I would fall asleep on the large peanut butter-colored leather couch in the front living room of Jennifer's house. Sometimes I would begin my Sunday afternoons at her house, and then leave with my high school friends for a drive to the mall or a trip to the movies. Other times, I would be working at one of my two jobs at the $163^{\text {rd }}$ street mall most of the afternoon and arrive at Jennifer's late in the evening. But, most times, most Sunday afternoons, I was on that couch. I would sit there, watch TV, eat, chat with the folks coming in and out of the house, and often fall asleep. Then I would be woken up-around 10 or $11 \mathrm{pm}-$ and told to get my stuff together to get ready to go home. It was a school night after all, and I, a high school senior, had to get to bed to ensure that I would wake up on time the next morning.

The couch was against a wall in the living room, facing the large television. To its right, was the front door of Jennifer's house. To the left of the couch was a long hallway with an unobstructed view through the formal dining room, the sitting room (with a slight view of the kitchen to the right of the sitting room), and the sliding doors leading to the backyard. Sitting there on the couch meant that I could be somewhat away from the commotion but not miss all the fun.

Sunday afternoons at Jennifer's was like being at church. The house was always full of people, eating, chatting, dancing, and playing dominoes. There was loud reggae music bursting through large speakers strategically placed throughout the house and the backyard. The kitchen counters and stovetop were covered with food-curry goat in pots, rice and peas, and brown stew chicken in large foil platters, bowls of fruit, and plates of sweet bread and other desserts. It was at Jennifer's house that I learned about the large and extremely diverse-economically, racially, and culturally-Jamaican immigrant community in South Florida. It was also through my connection and interaction with this community that I became immersed in a Jamaican cultural life. For example, I met and came to know Hector at Jennifer's house. Hector was described as a very white-looking "brownin" man. We jokingly called him "The Drunkard" because he was always, literally, drunk, and never steady on his feet. But he was funny, kind, and brilliant, and would spend hours chatting with my high school friends and me about school and politics. He would give great advice and would often tell us how proud of us he was for staying in school. Then there was Candy. Candy was also the mother of my high school boyfriend, Robert. She is the one who started bringing me to Jennifer's on Sundays. She would hold court on the other couch positioned diagonally from my couch against another wall in the living room. Candy would always be leaning back on the couch, very relaxed, but would get up every once in a while to smoke a cigarette or replenish her drink. Candy was tall and statuesque, young (for that crowd), hip and stylish, and fun. She seemed to glide around and through life with a smile and was always ready for a party. The men would flock to Candy, though she would often let them down with an easy smile. Through my young eyes, Candy seemed to be the life of the party, only second to Jennifer, in whose house we were.

Jennifer was the matriarch of the house and, based on these Sunday gatherings, she was a leader of the South Florida's large Jamaican immigrant community. I didn't know much about Jennifer. I still do not even know her last name. I met her through Candy and only saw her when she hosted these regular Sunday afternoon extravaganzas-or on the rare moment that she would attend one of Candy's own house parties. I do know that she owned a hair salon near the Mall at $163^{\text {rd }}$ street, and that many of her clients were Jamaican. That was all. In hindsight, and with age, I am in awe of the consistency of these Sunday gatherings. They were definitely not cheap to host, and they were a lot of work. There was always lots of food and drinks (liquor included), and many people stopped by just to have late lunch or early dinner. And by the end of the evening, the kitchen, dining room, and backyard would be a mess. This inevitably meant major cleanup for Jennifer and her family on a Sunday evening before everyone had to go to return to work the next day. Later on, after I had moved from Miami, I would often think of Jennifer's Sunday afternoon parties. And, these days, I wonder about the impetus for those gatherings. What made Jennifer begin hosting this event? How did she fund it? Did she have any specific hopes and dreams for the event? From afar, it seemed that 
Jennifer enjoyed having a crowd of people-her people-around her. She smoked much more than Candy, and my memory of her is that she would often be coming in from the backyard, cigarette in hand, heading to the kitchen counters to uncover more food trays to put on the dining table, as she is joking with guests in that comforting Jamaican patois.

I became a fixture at Jennifer's house on Sunday evenings after I left my own family's home at the end of my junior year in high school and moved in with Candy during the summer that followed. From the Sunday I decided not to go to church, the situation at home became untenable. And by the spring of my junior year, I was spending more and more time at various friends' houses, until I decided to not return home. While this was a tumultuous time for me, moving away from my parents opened up a whole new world. I had a freedom to participate in school's extra-curricular activities, as well as a social life with friends that I did not have before. In hindsight, I realize how dangerous it was for a sixteen-year-old Black immigrant girl to be tackling the world on her own. But it seems that I was also a self-directed child and cared deeply about school. It is almost amazing to me that my school work never suffered-through my ordeal of leaving home, being temporarily homeless, and working multiple jobs (by my junior year, I was working in three different part-time jobs)-and I never missed a day of school. And, when Candy asked me to live with her-having been told of my precarious situation by her son, my boyfriend-I maintained that pattern of work (at school and at my jobs).

Living with Candy and her two sons (my boyfriend, Robert and his younger brother) was an introduction to not only the South Florida Jamaican community, but also the neighborhood of Carol City and its seemingly large middle class African American community. I say "seemingly," because I used to be in awe of the nice and colorful large houses with fenced in tidy yards. This was very different from the Little Haiti neighborhood of my church community members, most of whom lived in large apartment complexes, and those who managed to find rental units in small dilapidated houses, certainly did not own them. And Carol City was undoubtedly different from our neighborhood in Miami Gardens. Thus, the fact that I could see Black families in and about their large, clean, and tidy homes meant, for me, that they were in much higher economic position than my family was. It was also important to see a different kind of Black American community compared to what I was presented with through the media and other sources. As first-generation Black immigrant kids, our views of African Americans were definitely shaped by the representations we saw on television or the way that that community was spoken of by both our white peers and our own immigrant families. To be clear, my sister and I had an exceptional experience in that we did not grow up around many African Americans families-especially as we moved into predominantly white neighborhoods in the northern part of the city that, though they quickly became Black, were peopled predominantly by Black immigrant families. Thus, what we thought we knew of African Americans was from the stockpile of racist stereotypes prominent throughout the 1980s: African Americans were presented as violent, drug-dealers who were not concerned with education. This was the era of the crack cocaine epidemic and the rise of popular TV shows such as "Miami Vice." And these were our references to the Black American community. Other immigrant kids-especially the ones in our church-actually had very different experiences with the African American communities. My younger brother and sister, for example, being a decade younger than me and my other sister, having been born in the U.S., and having to attend predominantly Black schools, were much more part of the African American community. Indeed, they were more African American than "Haitian." And they were the generation of kids born to first generation Haitian immigrants in the 1980s and 1990s. Being "African American" marked these second-generation kids in particular ways within the church community, and many had to navigate between both the extreme anti-American prejudice (and fear) of their parents and their lived realities outside the church, at school, and in their neighborhoods. These kids also had to navigate two sets of anti-Black stereotypes: "Haitian" and "African American."

For me, then, Carol City was a completely different escape. Before I had moved out of my family home, Robert had introduced me to the large public library-the North Dade Regional Library-near $27^{\text {th }}$ Ave, NW, and $183^{\text {rd }}$ street, Miami Gardens. This was the library used by most of the Black kids and community from the neighborhood (and those who attended my assigned high school, Norland Senior). This library was also closer to my house than the library on the campus of FIU that I used to go to with my wealthy white friends, but I did not know about it. And since Candy's house was closer to the North Dade Regional Library, we studied there more often. Working on school projects at the library also meant my socialization with the community and library staff. The other Black boy in my classes, the Jamaican-American, Kevin, also lived in what I considered a fancy house in and around Carol City. Thus, from working in the library, to attending parties in the community near Kevin's house and meeting his other friends, I was thrust into the middle class African American world of Carol City. And since Robert had a car, we were able to explore large parts of 
the northwest neighborhoods of Miami and socialize outside the predominantly white (East) North Miami Beach scene.

During the middle of our senior year, Kevin, who was also Robert's best friend, moved into Candy's house, too. From what I remember, his parents returned to Jamaica, and left him behind to complete high school. So the three of us non-related high schoolers were living in the same house! Kevin and Robert were the type of Black boys that did not readily fit the cultural and social milieu that I had become accustomed to, either at NMB or at church. They were extremely intelligent and, by the time we were high school seniors, they had gained much respect from the teachers and students alike in our Advanced Placement and honors classes. They were on the math team with me, but their skillset far surpassed those of the rest of us. In fact, they were two of the six students in a "Differential Equations" math class designed especially for them because they had surpassed all the highest high school math levels, including Calculus II. The two boys hardly studied, and were wonderfully arrogant, flaunting their lack of effort and high grades. But they were also extremely racially conscious, and decided, much sooner than me, that they would not be in a situation where they would have to tolerate the liberal racism that emerged in our academic and social settings.

Robert and Kevin dismissed that North Miami Beach social world, and instead found their place in settings that were, at first, unfamiliar to me. Robert, for example, made music. His father was a musician and had built a fully equipped recording studio in the garage of his house. Robert used to use his small, Macintosh Plus computer connected to a keyboard and a soundboard to make beats for hip hop songs. He spent hours in the studio, and made a lot of money as a teenager, selling beats to hip hop and rap artists. By the time we were all seniors, Robert and Kevin (with the help of Robert's father) actually managed an aspiring hip hop artist. Robert would make his beats, the artist would provide the rhymes, and the Robert's father would look for venues to book the hip hop artist, and I would sing some of the hooks for the songs. For a while this became our world-Robert, Kevin, and I. We all would rush home from school and head straight to the studio. This world also exposed me to the Black club scenes in South Florida, as we socialized, and even performed, in one club with the rapper. I was also introduced to the reggae club scene, primarily in Fort Lauderdale. Every once in a while, Candy, who loved to party, would dress me up in her clothes and make up, take me to reggae clubs, and tell the bouncers that I was her younger sister.

But life at Candy's house would take on a normalcy that I did not realize that I needed. I was still a teenager, one outside of the comfort of my own family, and needed loving adult support. Candy provided that. She was a young mother, having had Robert when she was just eighteen years old. She moved from Jamaica in her late teens and soon met and married Robert's father. By the time we were in high school, she was the single mother of two young boys. But she had a steady job at the telecom company-the same job she held from when she first arrived in the U.S. until her untimely death at the young age of 52. With her steady job, carefree attitude, and deep love for her boys, she managed a loving household. The house was large and comfortable, and Candy treated me like the daughter she never had. Through Candy, I also became an honorary Jamaican. I lived for her dinners of brown stew chicken and rice and peas, and for the Saturday morning ackee and saltfish and dumplings. Her Jamaican immigrant community embraced me, with friends taking me to run errands or substituting for my parents when I needed adult representation for school events. At the time, my world seemed full, despite being away from my own family. Being with Candy and her family provided me with new communities and a new outlook on life. It allowed, for me, the (re)making of a Miami community that was trans-Caribbean and proudly Black.

Thinking back on that Saturday morning in April 2013, as the limo raced down the Palmetto Expressway, I now realize that my father's death represents the death of an era and the foreseeable death of a geography. Little Haiti is disappearing, encroached on all sides by development and gentrification. The INS building is already being redeveloped as luxury condos. Peniel Church, my father's church, sits on what is currently prime real estate, and my mother and the church executive board are being continuously hounded to sell the building by real estate agents, business developers, and city officials. It is not clear how much longer they can stand firm-especially as the Haitian businesses and churches around them are quickly disappearing. In fact, just a year ago, I was being asked to convince my mother to sell the church building by a slick young Haitian-American entrepreneur who I met in a bar in the arts district in Miami. The heart of "Little Haiti," the $\mathrm{NE} 2^{\text {nd }}$ Ave corridor, may not last much longer. And if the fate of the first neighborhood and building that housed Miami Peniel Church is any indication, it is only a matter of time. That first neighborhood, a newly gentrified and expanded Wynwood, is now an area of white hipsters, bars with craft beer, and midcentury modern furniture boutique stores. The building that housed our first church is now a Ducati showroom. 


\section{Acknowledgements}

I am grateful to Donette Francis for her vision in this important project of naming, mapping, and archiving Black Miami. Thanks to Jafari S. Allen for helping to bring me into the fold. Thanks also to the anonymous reader for the generous reading and suggestions. And, as always, I am lucky to have Peter James Hudson in my corner as he provides critical feedback and unending support. I dedicate this essay to my mother, Lisette Pierre, and to the memories of Reverend Delanot Pierre and Marjorie "Cherry" Pengelly.

\section{Competing Interests}

The author has no competing interests to declare.

\section{References}

Danticat, Edwidge. "Trump Reopens an Old Wound for Haitians." The New Yorker, 29 Dec. 2017, https://www. newyorker.com/news/news-desk/trump-reopens-an-old-wound-for-haitians.

Goyanes, Rob. "Big History of Little Haiti." The New Tropic, 31 Jan. 2016, https://thenewtropic.com/ history-little-haiti/.

How to cite this article: Pierre, J 2020 Growing Up Haitian in Black Miami: A Narrative in Three Acts. Anthurium, 16(1): 8, 1-15. DOI: https://doi.org/10.33596/anth.376

Published: 31 March 2020

Copyright: $\odot 2020$ The Author(s). This is an open-access article distributed under the terms of the Creative Commons Attribution 4.0 International License (CC-BY 4.0), which permits unrestricted use, distribution, and reproduction in any medium, provided the original author and source are credited. See http://creativecommons.org/licenses/by/4.0/. 